\title{
J. TAKAGI, M.D.: THE STANDARD OF HEARING TEST ROOM VIEW POINT OF PERMISSIBILITY OF NOISE
}

\section{騷音許容値より見た聴力検查室の規格について}

第 2 篇 噍音下の聴力梌查について

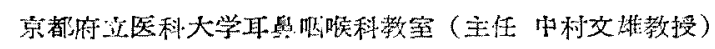

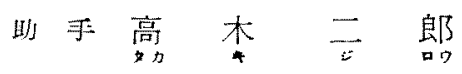

\section{第1章 絠言 \\ 第1節 測定方法 \\ 第1项 被 検 者 \\ 第2 項 测定埸所

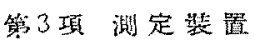 \\ 管 4 頊 使用した騒管 \\ 第5 項 测定闺法}

目次

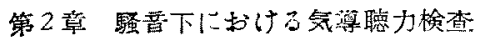

第 2 䬣 測定㖪紿

第3節 洘按並びに關値の検定

第 4 節 小括

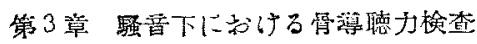

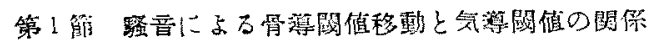

第2 節 测定方法

第3 穊 測定成維

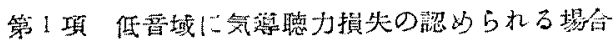

第2 項 高音域に気酎聴力損头の認的られる埸合

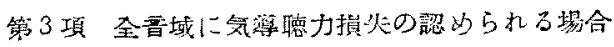

第 4 節 洘㧡並びに閶值の检定

第5 節 小 括

\section{第 4 章 総括・結諭}

\section{第 1 章 緒霉}

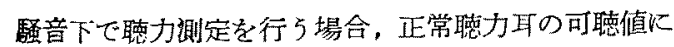
及ぼす騷音の Nasking effectについては前篇において 詳述した。しかし難聴耳の可埴值に及保すそれは正常耳 々は自导々異つて来るであ万万筆は容易に想像できる事

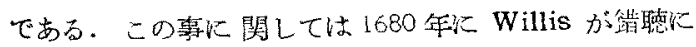
ついて報告して以来，数多くの研究加始められた。これ はその成續が聴覚機構の解明に大いに役立つからであ

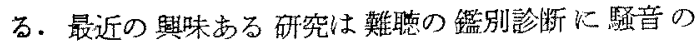
Masking effect 利用した事である。

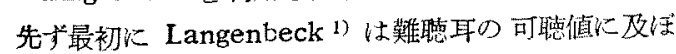

す騒音の影響を観祭する事によってとの鑑別が可能であ る事を述へた。同様の目的をるつて Weersmaミがそ

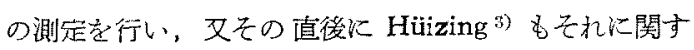
る羓踪を発表した。

しかしこれ等の 3 つ報告に括いては総て使用した虽 音の䧓波数分布が異なるためにその結論は信用できるか

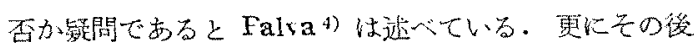
Langenbeck ${ }^{5)}$ は再び一定の周波数分布を持つた thermal noise を用いててその結果を報告し，次いで Kiety 6), Hüizingi), Zangemeister ${ }^{\text {() }}$ 等母 white noise 考用 いて Masking effect そついて観察し，難聇の鑑別を行 わんとした.

しかし1952年 Palva 4) は81 例の難聴耷について white noise による Masking effect を観祭した結果， 先の Langenbeck 等が見出した如き，事実を否定して Noise audiogram 飞よつては難聴の鑑別は 不可能であ

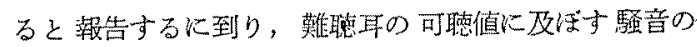
Masking effect については未解決の点の多い事が立証 された。

私も各種聴耳の可聴值に及活す騷音の影響を耕験して 一定の成績を得たので報告しょ5とするのであるが，私 の目的は先人の如く難聴の鑑別診断にあるのではなく， 騷音下聴力㭘查の絮限度を見出さんとして企図されたも。 のである。

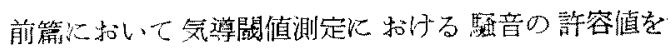

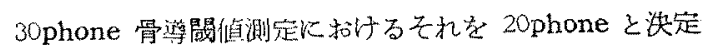

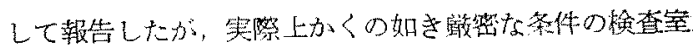
を得る事忧完俑せる防音窒以外は極めて困難である・し

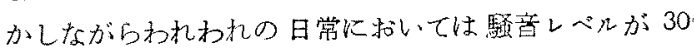
phone 以下であるらとなから5と与えられた 崖で炴查 を施行过权代ならない場合が多い事笑を考完る㭙，求少

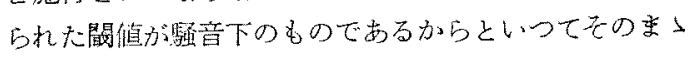

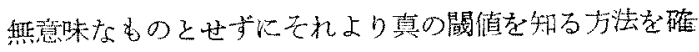


施せねばならぬ。

この闍題に閣しては先に立木のがある限度において それは可能であるとの結論を報告した。

私は更にこの問暹を検討するだ, 各稙の難聴耳に及 ぼす驧音の影響を観察し2，3の知見を得る事ができた のでこ、に報告する次第である。

\section{第 2 章 騒音下における気遒聴力模查}

第 1 筑 测定方法

第 1 項 被 検 者

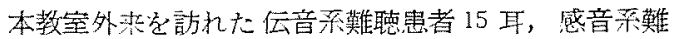
聴虫者 8 耳，混合性難聴患者6耳，及び正常德力者6耳 （教等冒）至被険者として测定を行つた。

第 2 項 湘定場所

测定はすへて本教室防音室内でこれを行つた。

第 3 項 湘定器具

小林理面: 1A 1002 Audiometer

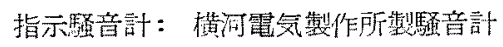

減衰器：日本霆子測器製作所整娍衰器

Taperecorder: Philips 会社製 Taperecorder

第 4 項 使用した騒音

本研究の目的からすれば测定に使用する騒音は一般騒 音を用いるのが適当である・しかし前篇の实験により街 頭騒音とモータ一騷音に和いてはその level の変動に おいて差買のあるのは勿論の事であるが，その周波数分 布，あるいは可聴值に及注す影響は大差のない事が判明

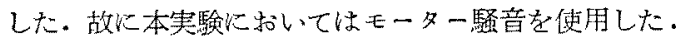

第 5 項 测定力法

騒音下で求めら玌た難聴耳の閾值より真の關值を推定 するには，その检查室に和ける聴力正常耳の閶值移動を 基準としてこれを行うのが最る便利である。そこで防音 室内に扎いても一タ一騒音を平均レベル 30，40，50，60

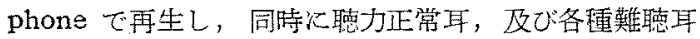

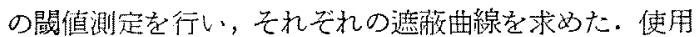
したモ一タ一㐨音は前篇において述心゙た如く低い周波数 の検查音に哮して，その Masking effect が大で，高い 周波数の検查音に対しては小であると云万事实，亚びに 同一難聴耳にしても周波数の高低によって聴力損失の程 度が是なると云52つの理由から同一被检者に赫し,

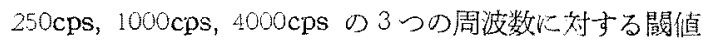
の移動を锶系した。

第2 筑 测定成績

第1龱は基潐となる心゙き聴力正常耳可恥閾值のモータ

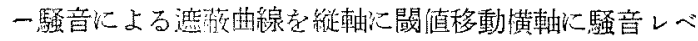

ルをとつて表わした図である。

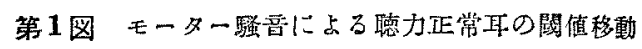

1) 250 c.p.s.

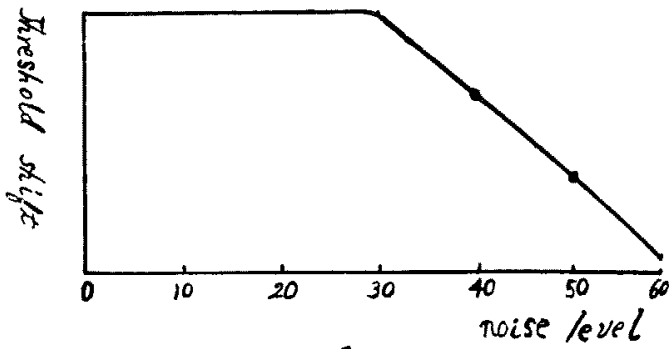

2) 1000 c.p.s.s.
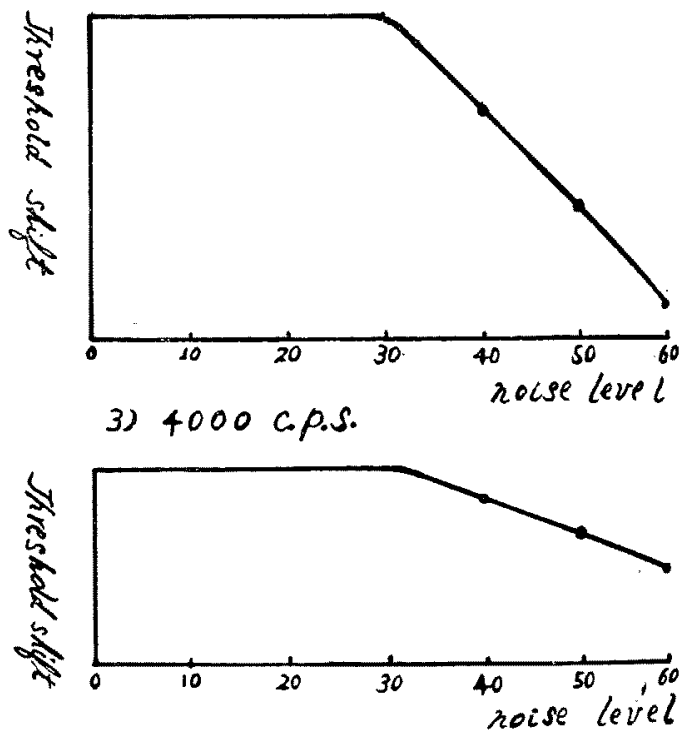

難聴耳の遮蔽曲線は難聴の程度，種類の差暴によりそ れぞれ異つた型の曲線ができる事は容易に想像し得るが 今聴打正聴耳の遮蔽曲線を基準としてこれを2つの型に 大别して洘える・即ち第 1 型は第2罒に示す如く聴力正 常耳の遮霰目線と交叉する迄は間值の移動を示さない型 でこれをA型曲線と仮称する。

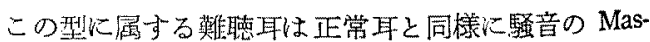
king effectを受けるか，又は正常耳よりも Masking effect を受け難い・性留の本のが含まれる.

第 2 型は第 3 図に示与如く聴力正常耳の遮蔽曲線と交 攴寸る迄に䦪值移動を示す型でこれをB型曲線と仮称す る.この型には正常耳よりも顕著に騒音の Masking effect 产受ける性筫のるのが含まれる。 

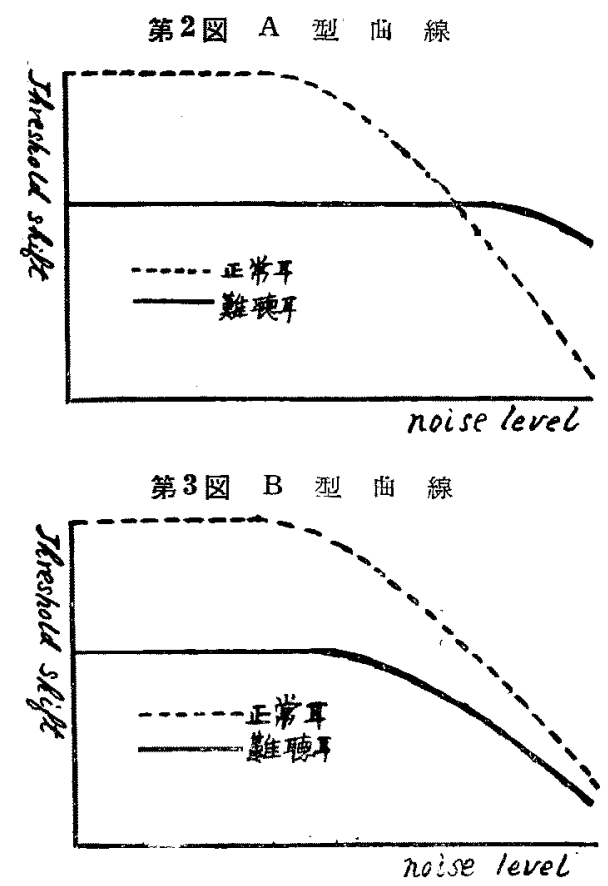

各種萁焦聴者29吕について各今 $250 \mathrm{cps}, 1000 \mathrm{cps}, 4000$

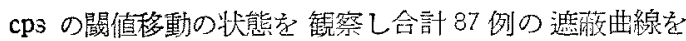
求めた・しかし慕聇耳といてとも周波数によつて正常聴 力を示す場合があるのでこれを除く64例の遮桃曲線よ り A 型曲線，B型曲線について観察学行つた。

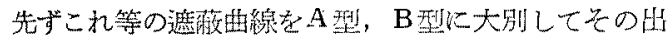
現率安みると第1素の如くで㟒名。

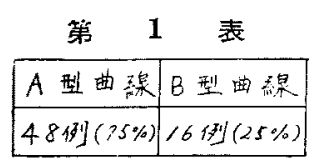

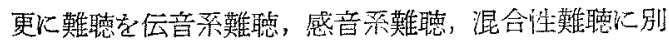
け，雨曲線の出現率を観察した結果が筹2 表で焉る。

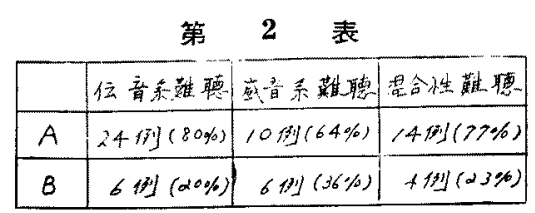

後述することであるがA型曲線を示す難聴耳の䖪音下 で求められた閔值の恰討は比較的容易に，又比較的正礁 にこれを行う事ができる。しかしB型曲線を示主嚾聴耳 の闇值の検䚯はある程度の限度を設けなければはなはだ
誤差が多くなり帮際的に不可能となる・何故ならばこの 種の難聴は正常耳の間值移動の檤から難聴耳の間值移動 の値を推定する事が不可能であるからである。故にB型 曲線を示す難聴耳に関しては更に梁く観察しなければな

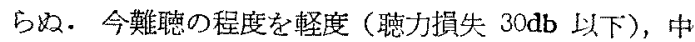
等度 (螅门損失 $30 \sim 60 \mathrm{db}$ ), 高度 (聴力損失 $60 \mathrm{db}$ 以上)

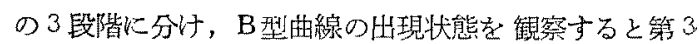
表の如き結果となる。

\begin{tabular}{|c|c|c|c|}
\hline & 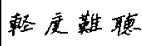 & 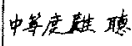 & 高里踓琶 \\
\hline 伭音系䓚㯖 & 6 & 0 & 0 \\
\hline 威音系赫㯖 & 3 & 1 & 2 \\
\hline 混合性覲猡 & 3 & 0 & ' \\
\hline
\end{tabular}

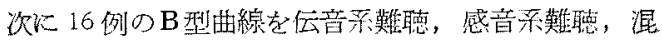
合性難聴別に示すと籍 4 : 圂の如くで古る。

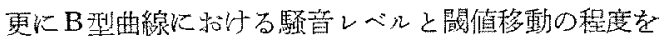
観察すると第 4 表の如くである。

第3節 考接並びに閥值検訬について

虽音下で求められた難德耳の閶值梌討には先ず正常耳 閶徝の䟥音に上る移動を知りこれを基蕉として行うのが

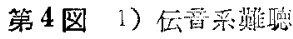
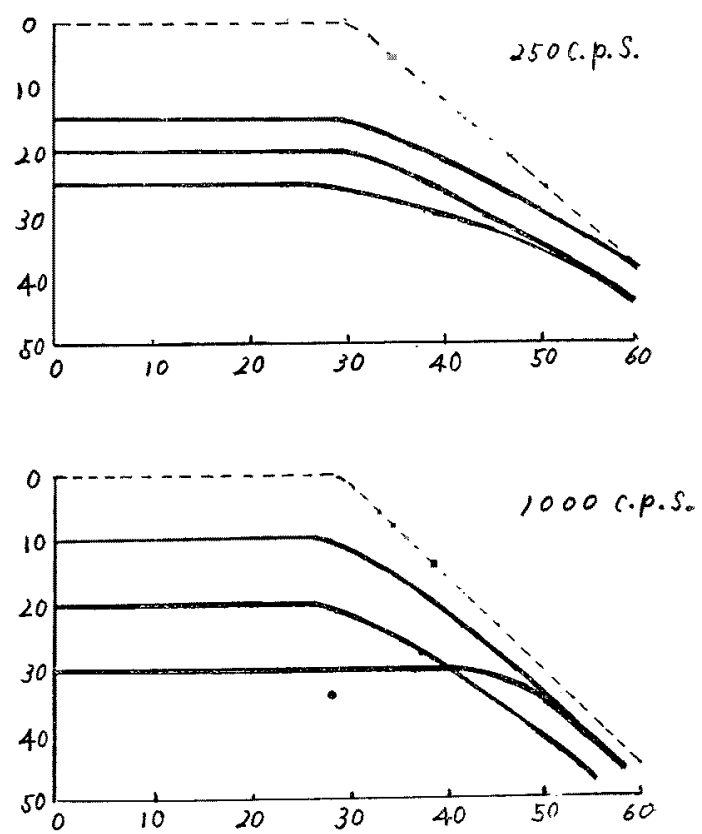


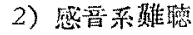
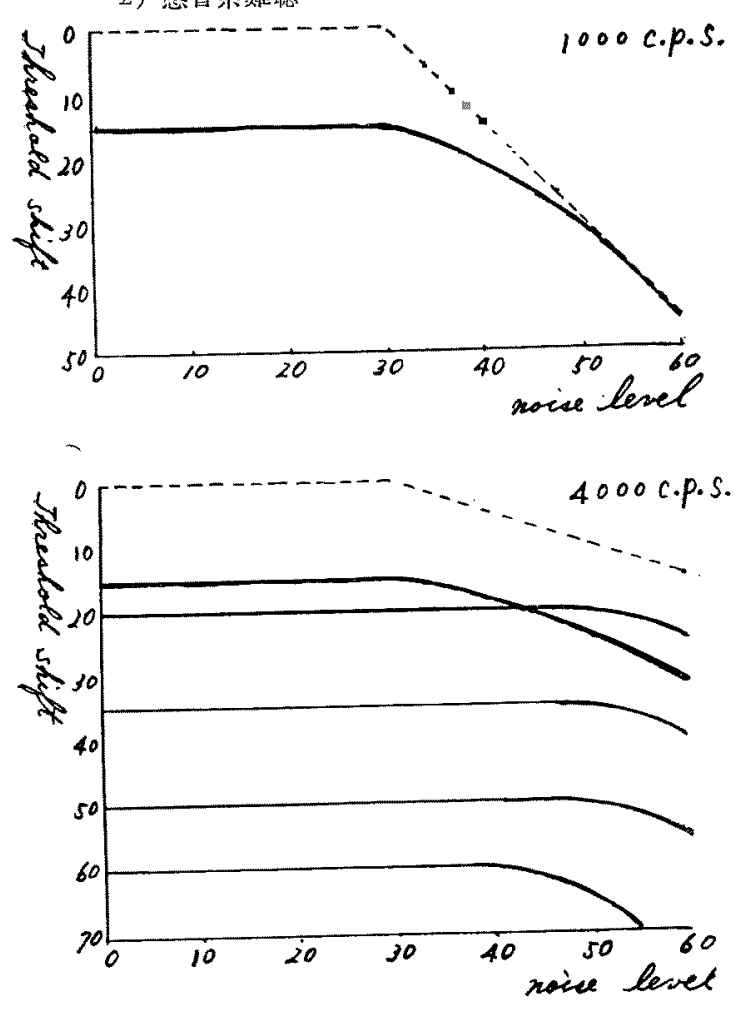

3）混合性䩤德
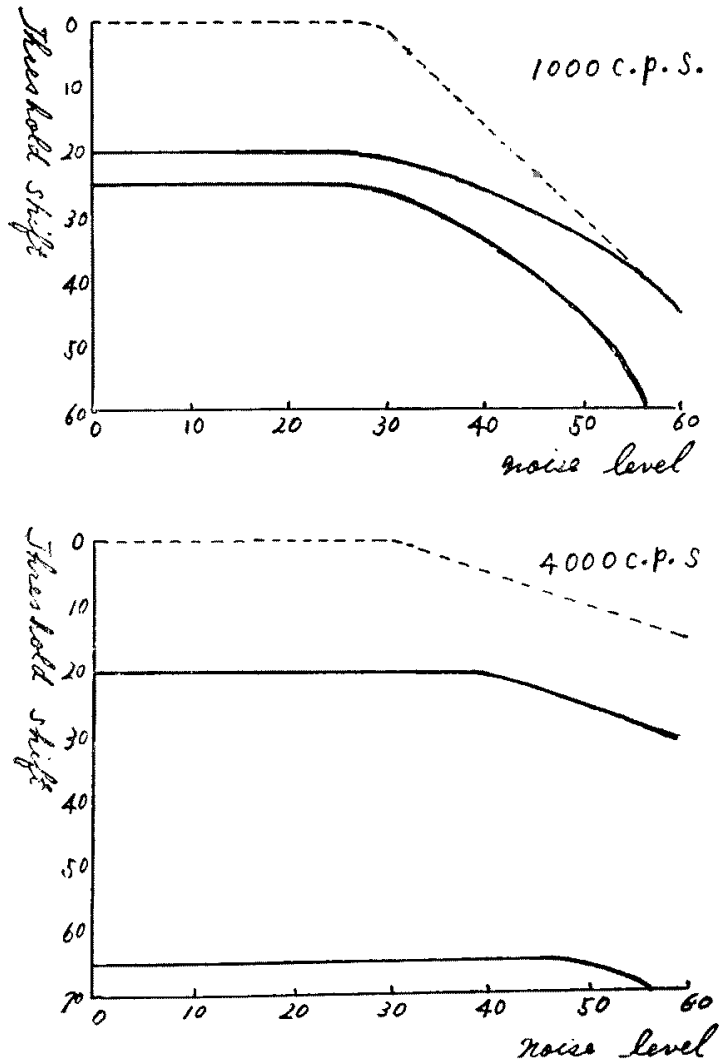

\begin{tabular}{|c|c|c|c|c|c|c|c|c|c|}
\hline 第 4 & 表 \\
\hline 40 & $0 \mathrm{db}$ & $5 \mathrm{db}$ & $10 \mathrm{db}$ & $15 \mathrm{db}$ & $20 \mathrm{db}$ & $25 \mathrm{db}$ & $30 \mathrm{dt}$ & $35 \mathrm{db}$ & $40 \mathrm{db}$ \\
\hline 40 & 8 & 6 & 2 & 0 & 0 & 0 & 0 & 0 & 0 \\
\hline 50 & 5 & 2 & 2 & 5 & 2 & 0 & 0 & 0 & 0 \\
\hline 60 phexs & 0 & 3 & 2 & 2 & 1 & 4 & 3 & 0 & 1 \\
\hline
\end{tabular}

便利である.この基隼となるべき埴力正常耳のモーター 騒音による遮蔽曲線は第1图に示した。使門したもータ 一騷音の周波数分布の特性からその Masking effectは White noise 等とは自ずから異なつた態褰をとつてい る. 即ち $250 \mathrm{cps}, 1000 \mathrm{cps}$ の低音域代对してはその Masking effect は大であつて 4000cps の高音域に対し ては Masking effect 忯である。これは㯰力正常耳の

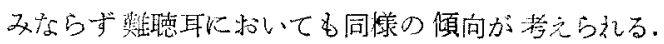

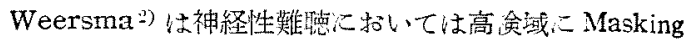
effect が著明に行われると述ぐているが，これは Th

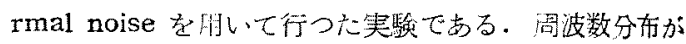

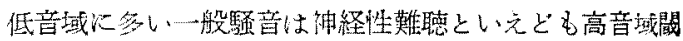

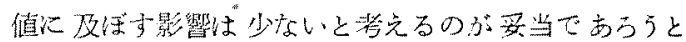
思 5 .

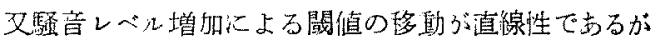
非直線性であるか火䦔しては古来種っの議論がある。即 ち Langenbeck 5) は非直線性で岕ると主張し，一方

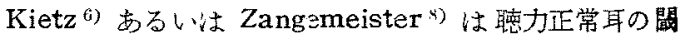
值は直線性に移動すると反対の立場をとつた。悡の行つ

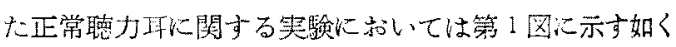

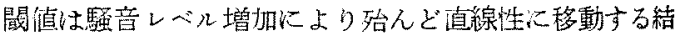
果を得た。

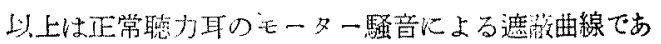

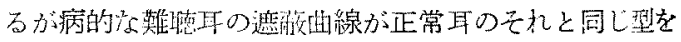

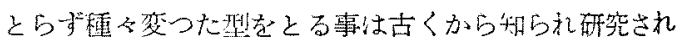
ているとこるである。私は前項化つつき本篇に和いては

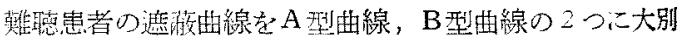
して観察した。

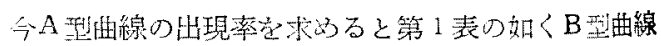

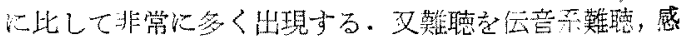

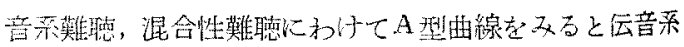

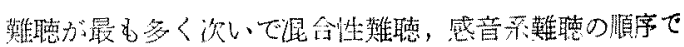

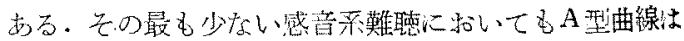
B型曲線に比して相垱多くの出現率を示す。

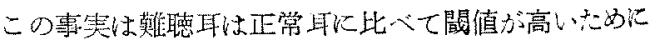

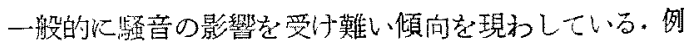
へばレペル a phose の騒音が正常聴力耳几影響する実 
効量は a phone でちるが難聴耳に影響する実効量さ

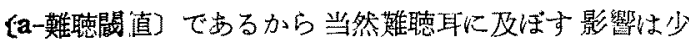
ないわけである・しかしながら騒音の難聴耳に及ぼす影 謷はかくの如く簡篻に算出できるるのではなくその坼に 種々の難しい要因が介入する２，3の例を示すと次の如 くである。

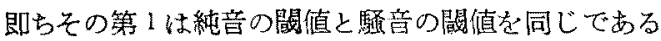
と考えて良いか，即ち先の例から云えば難聴耳に及ぱす

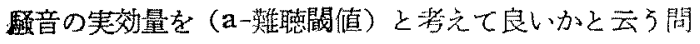
題である. Lang 3nbeck ${ }^{10)}$ はこの筆に関して次の如く 速べている、即ち彼はすべての层音系蜼聴及び聴力損失 が 30〜40db 以下の感音系難聴に和いては騒音の闌值と

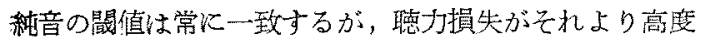
の感音采難聴においては騥音の䦪值は紌音のそれより一 般に低く，時には 15〜20db低い場合が方ると述べてい る.この点は更に检討を要する結腀であるらと考光る。

第2に Recruitment の問題である. Recruitment

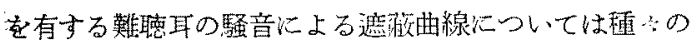
䧧論がある. Langenbek II)は Recruitment を有する 難聴耳は騒音の Making effect壱受け難いと唱へ，又 Kietz ${ }^{6)}$ は静寂な場所上りも騒音の存在する場所に才け る方が純音に対する間值が低く而車 Recritment

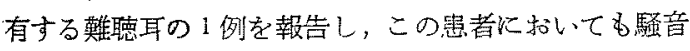
の Masking effectは現わ扎難からたと陧へ Langæn beck と同樣の立場をとつた。 しかし1950年 Zangem eister $は$ Labyrinth hypertension で Recruitment を有する整者に拈いて Masking effectの著明に行われ る1例報告し, “更に Hüizing ${ }^{7}$ は1952年に Recr. uitmentを有する患者で騷音による闒值移動が正常耳 のそれより 15〜20db 多い例を報告した．Recruitment の本態も未だに解明されて拈らず，更に Recruitmっnt

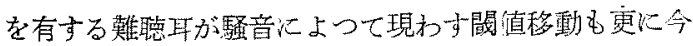
後研究され权ばなら問題である。

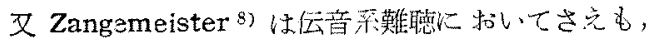

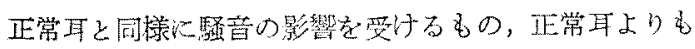

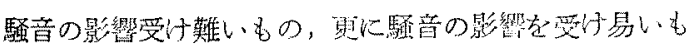
の১3つの型があると述べている。

以上の如き複雑な要因のために一般に踽音の影留を曼

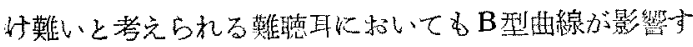
るのであろ5と考觉る。

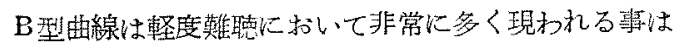
第了表に示す如くでする。位音系蜼聴の如きは6例のB

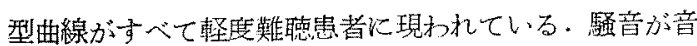

響学的に検查意に対して Masking effect 教直するの

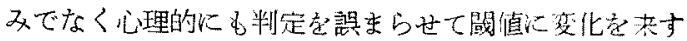
であるう事は容易に想像できる亜である、殆んと正常耳

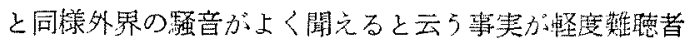

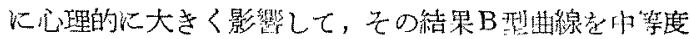

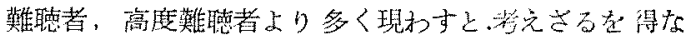

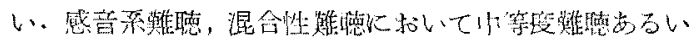

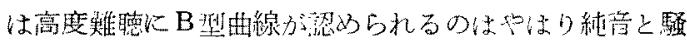

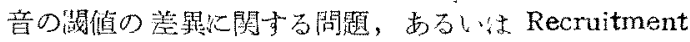

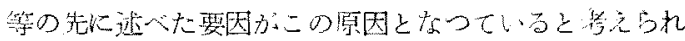
๖.

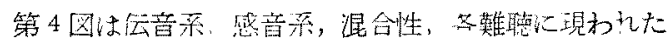

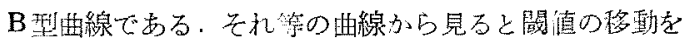

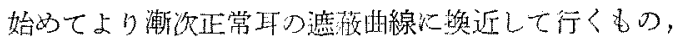

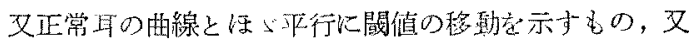

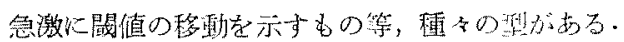

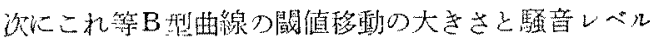

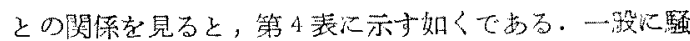
音の影智を受计易いと考えられるB型曲線儿おいて子平

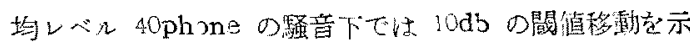

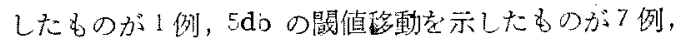

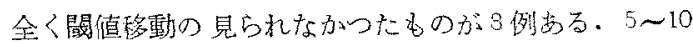

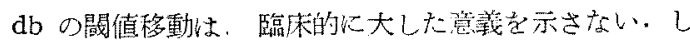

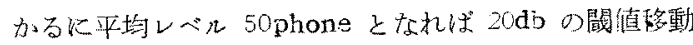
2 例， $15 \mathrm{db}$ の闎檤移動か 5 例等相当の移動起示求

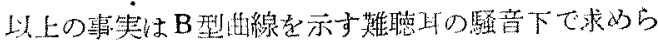

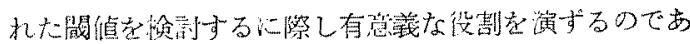

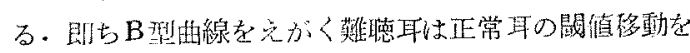

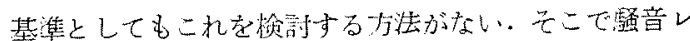

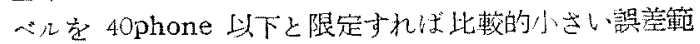
囲て积討できるのであるが 40phone 以上 5ophone K なれば 15〜20dbの相当大きい愦差を生ずる。

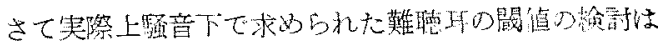
どすよラにしたら息いであるらか

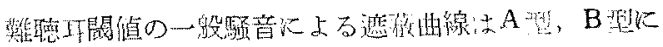

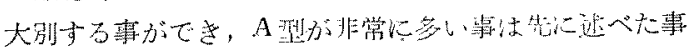

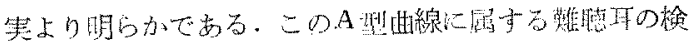

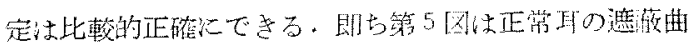
線孝A型曲線の関保定示したものであるが国者がかくの

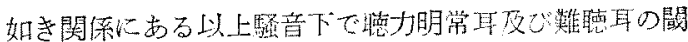

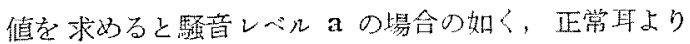

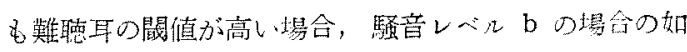

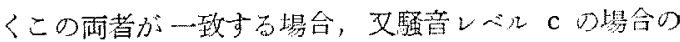


第 5 图 A 型曲線の闌詙検定

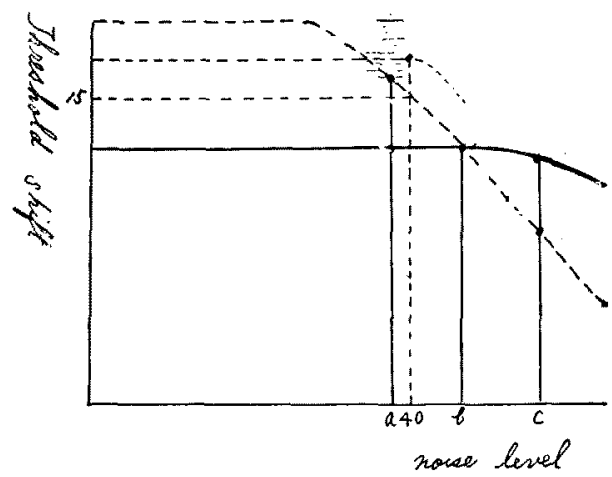

如く難聴耳の㪄值が正常耳のそれより低い場台が現われ てくる．実際上検定できるのは虽音レべル a の場合の

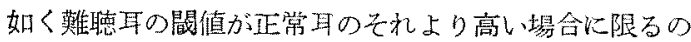

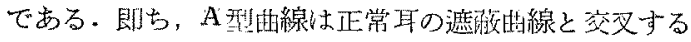
迄は間值の变動を現わさないと云う性潩が茄るため，難

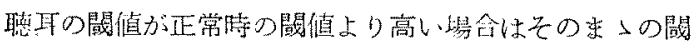

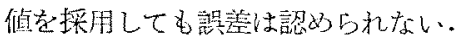

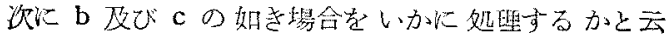

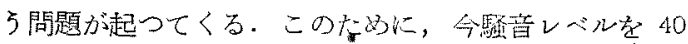
phone 以下之限定寸机埴力正常耳の最大の䦪值移動

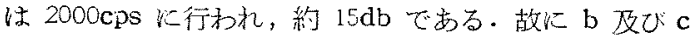

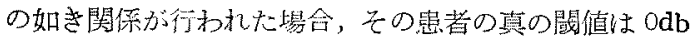
が $15 \mathrm{db}$ 迄の閶にあるのであつて臨床的には殆んど正

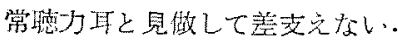

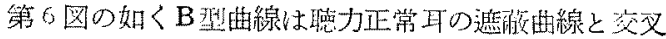

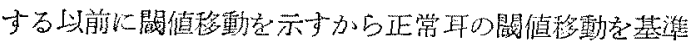
としてこれを梌討してもをこに誤差を生ずるのは止しを

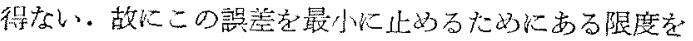
設けなければならないのでする。

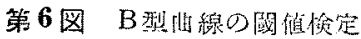

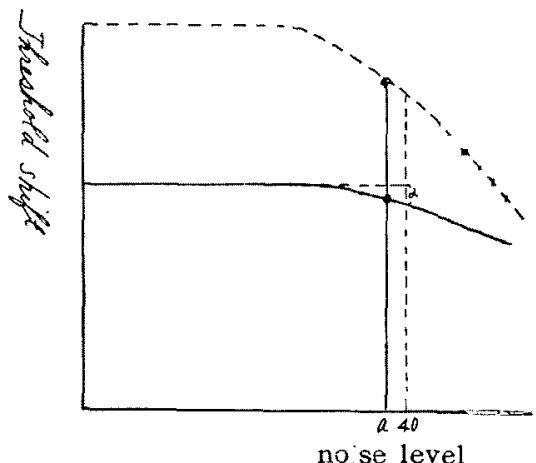

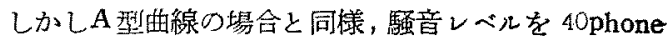
以下と限定すればその場合の闒值移動は5〜10dbであ る. 又B型曲線に执いては 40phone 以下であればb及 びcの如き関係は殆えど生じないためややはり正常耳 の閶值より難聴耳の閔值が高い埸合はその閭值を採用し てその湘定部差は10db 以内であるとする事ができる。

しかし実際上騒音下で聴力検查を施行するにあたつて われわれ恃患者の聴力がA型曲線を画くか，B型曲線を 画くか性前もつて知る事はできない、いずれたせよ舅音 レべルを40phone 以下と限定すれば，その蚞查宝に挂 ける患者の闒值が正常耳の闒值より高い場合その值を採 用してもとの誤差は極めて少ないという結論が出せる。

第4 節小括

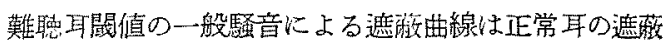
曲線を基隼としてA 型曲線，B型曲線に大別する慗がで き.一般にA型曲線の力が多い。

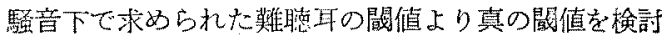

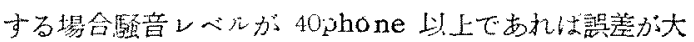
きくなる。

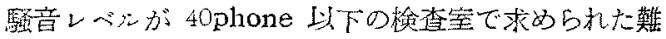
槙耳の閾值が同室で求められ九正常耳の䦪值より高い場

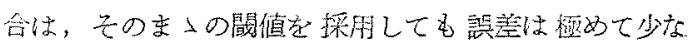
i.

\section{第3章 騒音下における骨寧聴力検查}

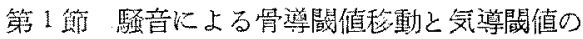
関係について

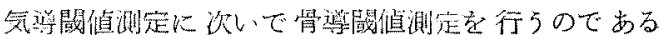

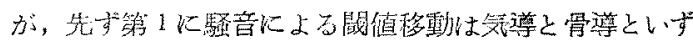

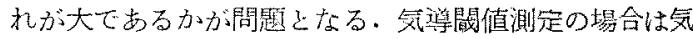

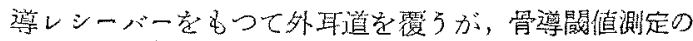

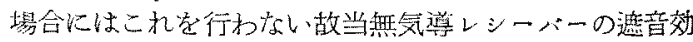

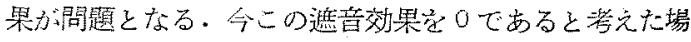

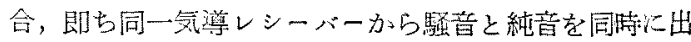

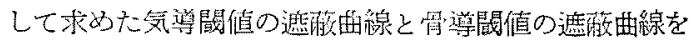

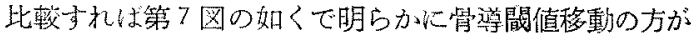

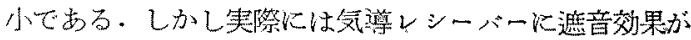

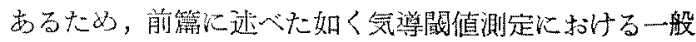

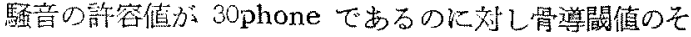
れは 20phone であり，又平均レベルが 40phone の騷 音下に扔いては正常耳の閔值移動が気導では $15 \mathrm{db}$ ，骨 滔では $30 \mathrm{db}$ の值を示す結果となつている・即ら, 気導 に比して骨導は騷音によつてはなはたしく移動する事実

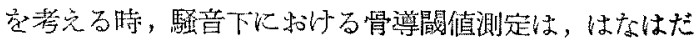




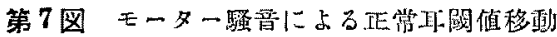
A 気 薄

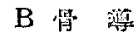
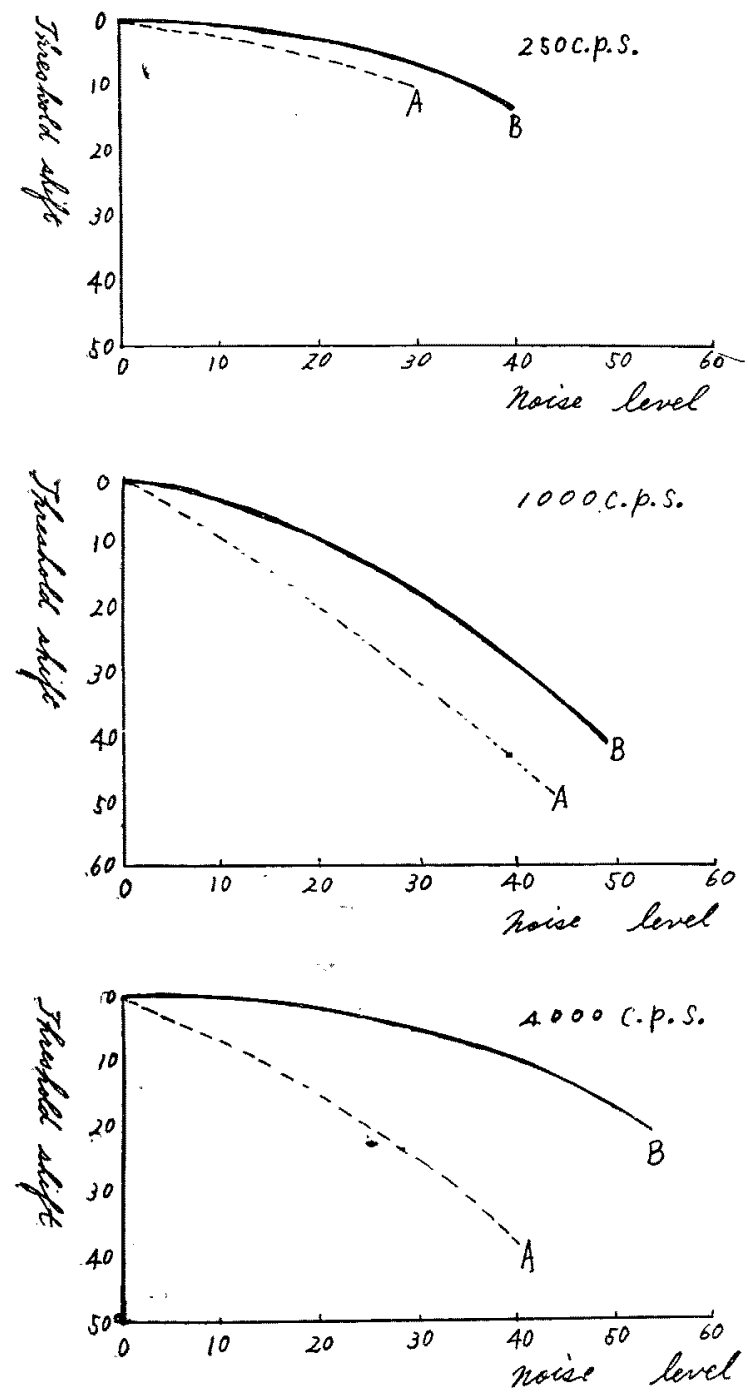

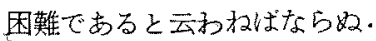

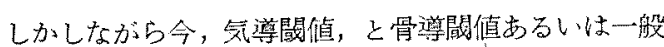

䃨音の Masking effect に次の如き閔係が存在する事を

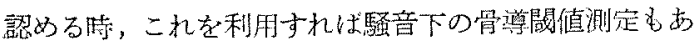
る程度可能となるのではないかと㵭えられる・即ちこれ 匴三者の間以は

（I）一般に骨導閶值は気頱間值と一致するか，又は 気等㹇值より低い埸合が多い。

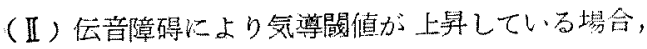

骨導䦪值は騒音の影響は受け難い。

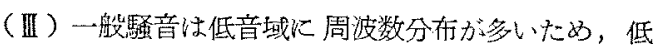
音に対しては Masking effectが大であるが高音に対し ては小である。

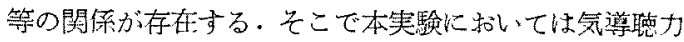
曲線の性筫に征い次の如き3つの場合に大别して考察を 谯めて行くのが便利で岕ると考える。

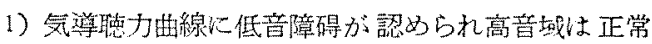
近い場合

2）気洋聴力曲線に高音障碍が認ふられ低音域は正常 化近い場台

3）全周波数に亘り気導閶值上昇を認心る場合

第 2 節 测定方法

被検者は本教害外来を訪れた各種難聴患者を用いた。 湘定埸所，测定器具，一般騒音に上る遮霜曲線の求め力

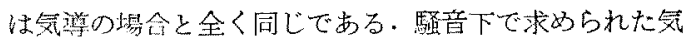

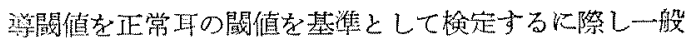

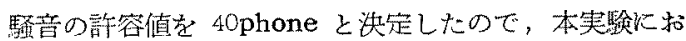
いては先す縣音の限度を40phone と洪め，この条件で

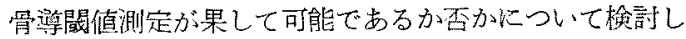
t.

第 3 節 测定成績

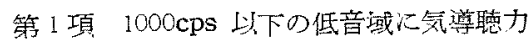
損矢を認める場合

1) 気摹聴力損失が $30 \mathrm{db}$ 以下の軽度な埸合

即ち第8图 Audiogram に示す如き場命である。こ

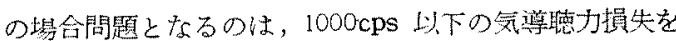
示している周波数の骨望㯖力である、そこでかくの如き 德力像夲示す患者 5 名 8 耳の $250 \mathrm{cps}, 500 \mathrm{cps}, 1000 \mathrm{cps}$

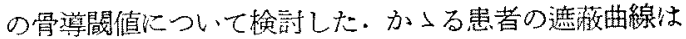

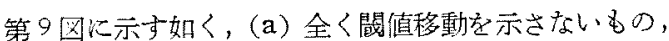
(b) 䦪值移動を示しても正常者のそれより榦度なもの， (c) 正常者と同様の閏值移動を示すもの〉3つの型の曲 線が出現して来る。2 例の遮茨曲線を a， b，c型に分 類寸れば第 5 表の如くである。

2) 気導䍡力損失が $30 \mathrm{db}$ 以上である埸合

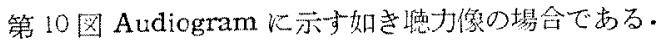

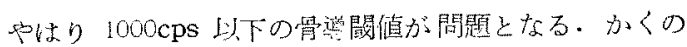

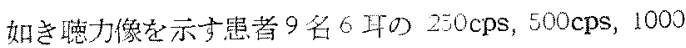

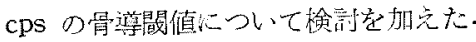

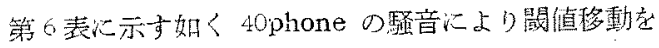
示したもの篗か1例で他は全く閶值の移動示さなかつ た・而して1例の間值移動は $5 \mathrm{db}$ に過琶なかつた。 


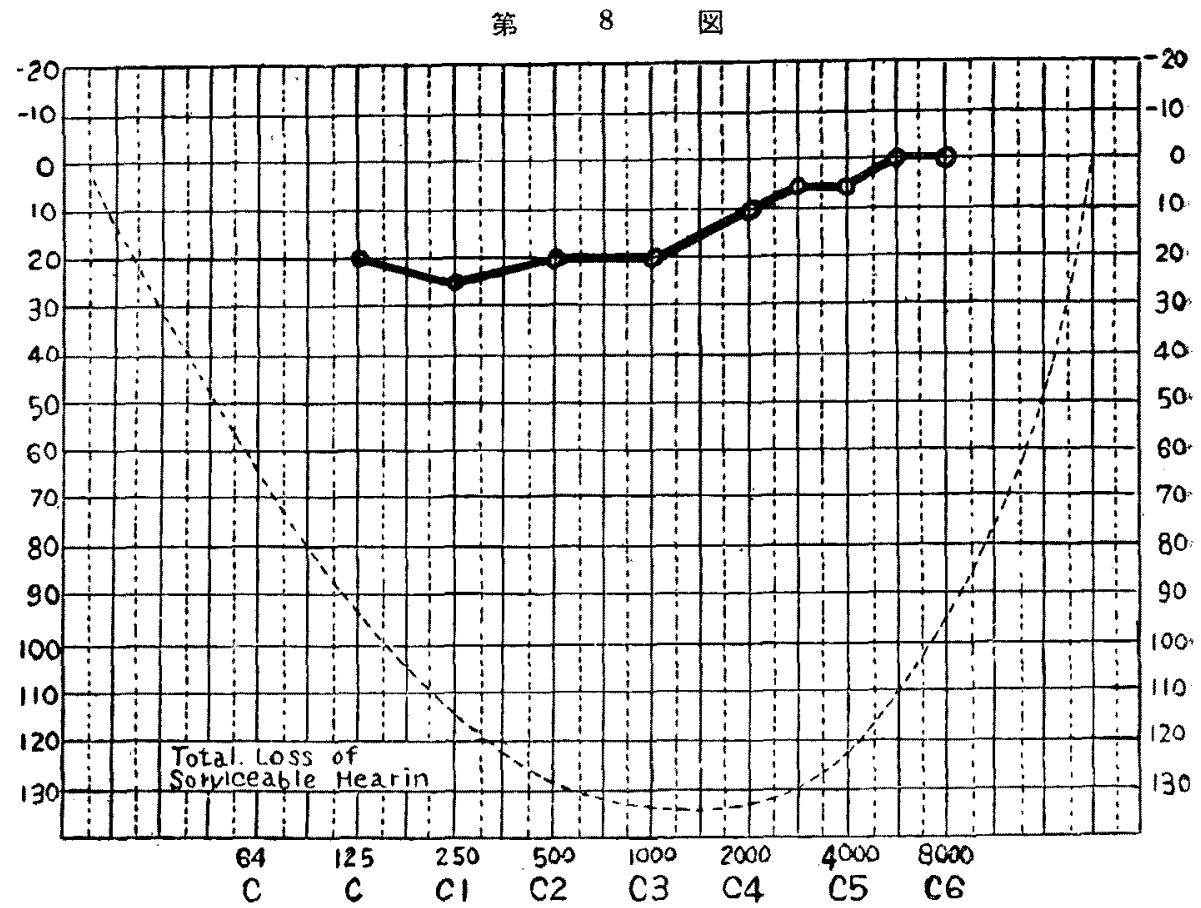

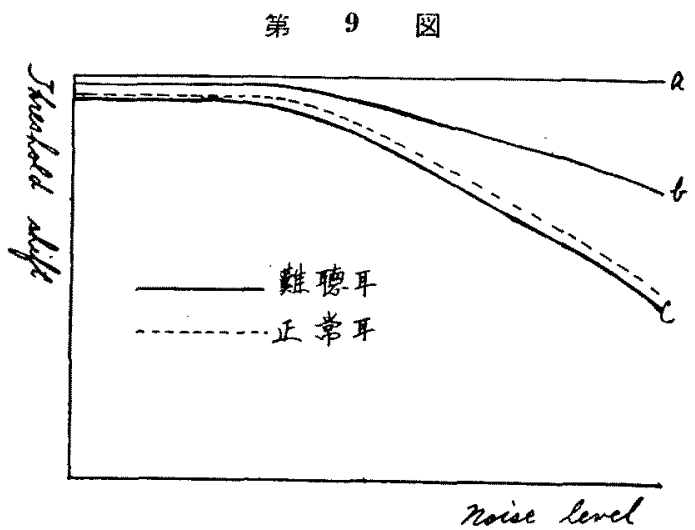

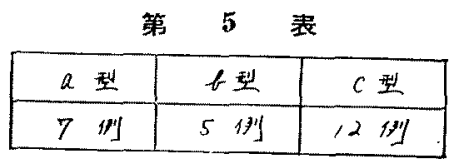

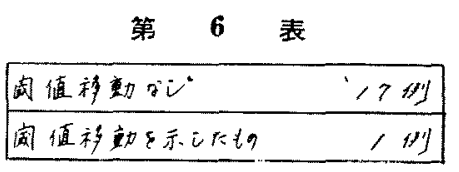

第 2 項 $2000 \mathrm{cps}$ 以上の高音域に気導聴力損失

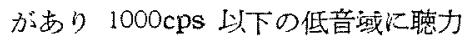
損失を認めない場合

即第 11 図 Audiogram に示吉如き聴力像の埸合で おる.この堭合は $2000 \mathrm{cps}$ 以上高音域の骨導閶值が要 求せられる・患者 9 名 10 耳の $2000 \mathrm{cps}$, 400cps の骨導

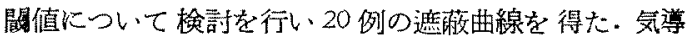
の埸合と同様 $\mathrm{A}$ 型，B型曲線に大别すれば第 7 表に示す 通りである。

更に現われたB型曲線を㪕度，中等度，高等雑聴に別 けて考壳ると第8表の如くである.

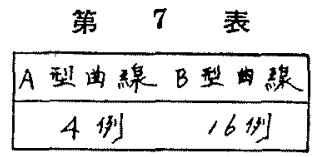

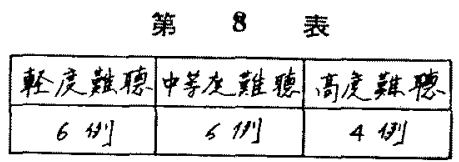

第 12 図はB型曲線を示したものである。

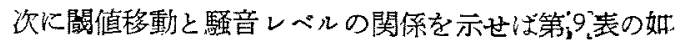
くである・ 

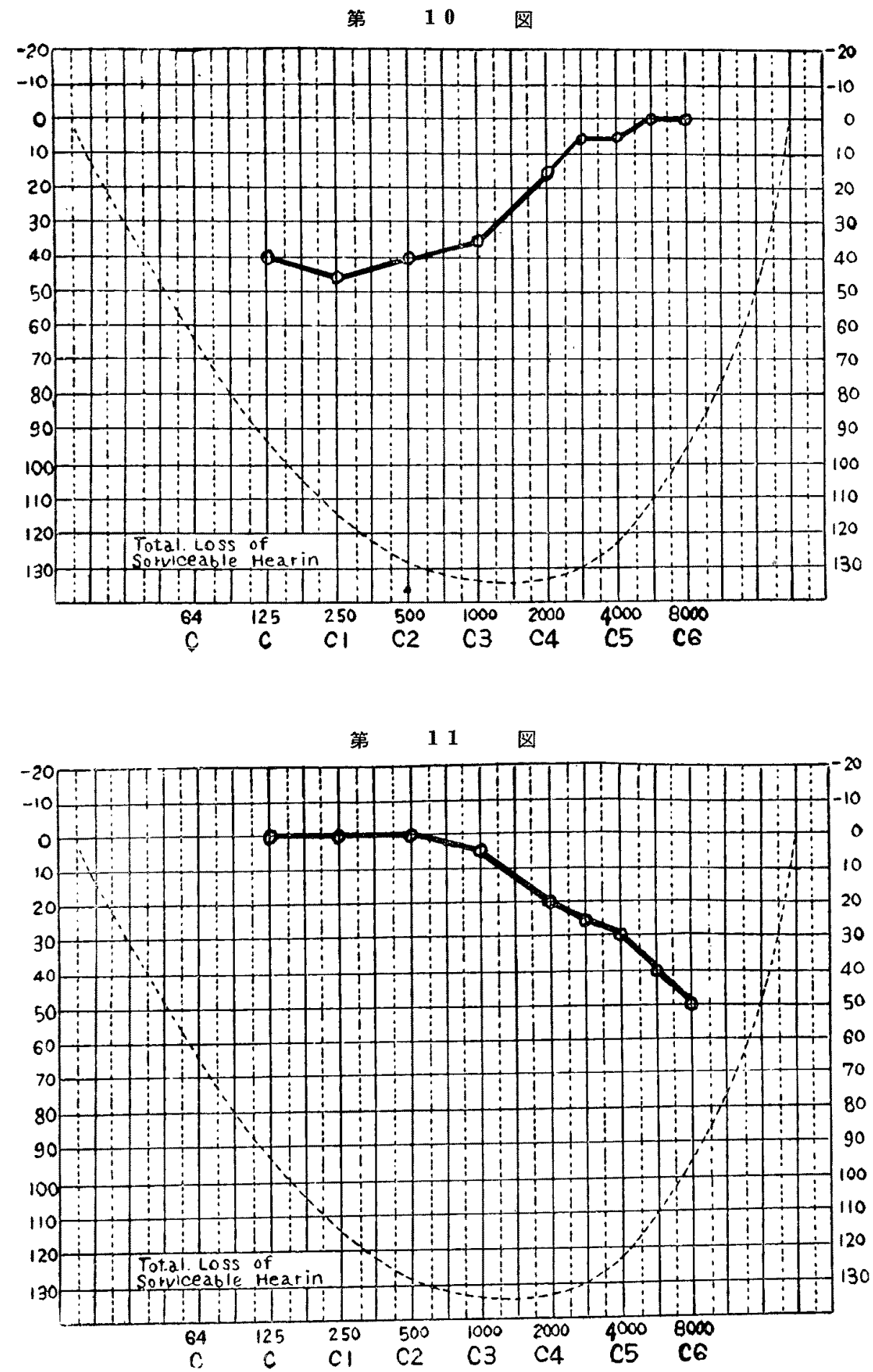

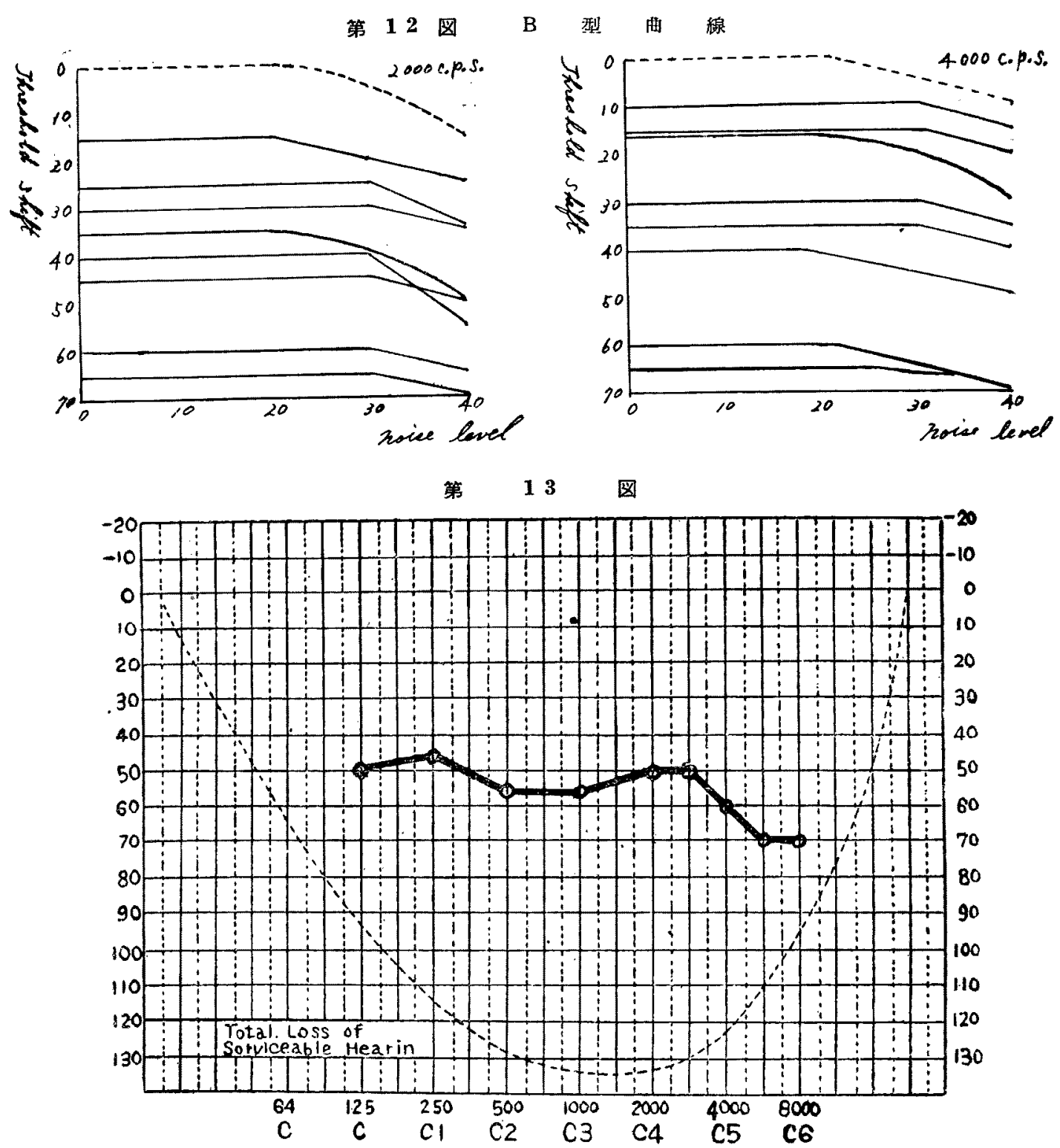

第 9
\begin{tabular}{|c|c|c|c|c|}
\hline & $0 d b$ & $5 d b$ & $10 \mathrm{db}$ & $15 \mathrm{db}$ \\
\hline 30 phone & $11 \mathrm{~d} t$ & 5 & 0 & 0 \\
\hline 40 phone & 0 & 9 & 4 & 3 \\
\hline
\end{tabular}

第3 项 全音域に気㩐聴力損失を認める場合

第13図 Audiogram に示与如き聴力像の場合である. この塄全は全周波数の骨導聴力が問題となる．全周波数

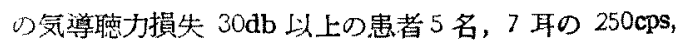
$1000 \mathrm{cps}$, $4000 \mathrm{cps}$ の骨導閽值について検討した. 21 例

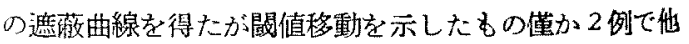
は全く間値の移動を見なかつた. 又2例の閥值移動は理 か 5dbであつた。

第 4 節 考 按

1）低音域に気導聴力損失のある場台

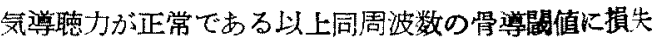


のある場合は殆んど存在しない，故にこの場合高音域の 骨導閏值は正常であると見做して差支えなく，問題とな るのは低音域の骨導曶値である. 又かくの如き場合気尊 聴力損失が $30 \mathrm{db}$ 以内であるから骨導聴力損失も $30 \mathrm{db}$ 以内であると想像でさる。しかし気導聴力曲線について 考文ると低音域のみに損失のある場合は㱠んど伝音采䧼 聴である場合が多い、低音障碍性感至柔難聴については 私はからてその 1 例を報告し，又中村はその存在の可能 性について梌討したが，その存在は極めて稀である。こ と汇気導德力損失が 30db 以下である時は伝音系障碍で あるとして骨導聴力に損失なきむのと考えて差支えない と思われる。

又伝音障碍のため, 気導聴力比 $30 \mathrm{db}$ 以上の損失のあ る埸合は第 6表に示した如く騒音レベルが 40phone 存 在しても閖值移動を示すものは殆んどなく，存在しても 誤差籁囲之考光られる小さい值である。

気導鿵力の低音障碍が感音係障碍によるものであるな らば騒音による骨導閣值移動は伝音障碍の埸合々異なつ た形となつて行われるであるろ事は想像できるが，前述 の如くかくの如き埸合はきわめて稀であり，未だ観察す る機会がない。これは今後の問題であると思 5 .

2) $2000 \mathrm{cps}$ 以上の高音域に気尊聴力損失の ある場合

この場合，高音域の気導闒值が上昇しているにも拘ら す騒音のために，骨導閶値が移動する。この事奏より洘 之ると一般騜音の周波数分布が低音域に多いため，一般

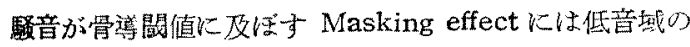

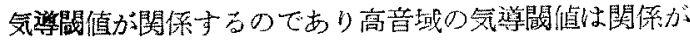

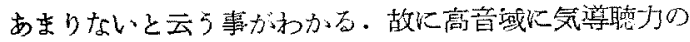
損失があつてもこの事は，騷音下で求められた骨導閾值 の検討に際してはい寸㞦の基準ともなり得ない，そこで 求められた遮蔽曲線を $\mathrm{A}$ 型曲線. B 型曲線に大別して観 察してみると，第 乙表に示寸如く気尊の場合と異なつて $\mathrm{A}$ 型曲線が少なく $\mathrm{B}$ 型曲線が多い，次いでB型曲線の出 現率学軽度難聴，中等度難聴，高度難㯖に分けて推祭す

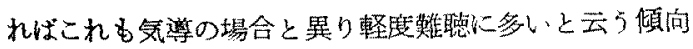
は全く認められない.これ等の事実は気導の場合は䦥値 が上荊していれは騷音の影響を受け難いと云5一般的な 傾向が存在するが管導の場合はこの傾向があまり顕箸で ない事を示している。低音域の気導闒值が正常である限 り，外界の一般騒音のエネルギーは正常耳と同様に内耳

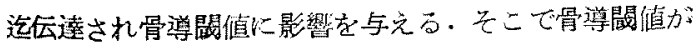
正常である場合と上舁している埸合と全く同様の影響が
認められるかと云えば，第11図及び第9表に示す如く である，即ち騒音平均レべルが 30phone の場合は正常 耳の閾淔移動は $2000 \mathrm{cps} て 10 \mathrm{db}$ に対し難聴耳は $5 \mathrm{db}$, 40phone 9場合正常耳 $15 \mathrm{db}$ に対し難聴耳 $5 \mathrm{db} \sim 15 \mathrm{db}$

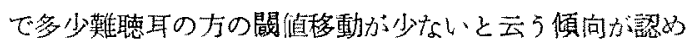
られる。

3）全音域に気導德力損失の認如られる埸合

かくの如き気導曲線を画く難聴は混合性難聴である場 合に一般に多く認められるが，やはり低音域つ聴力損失 は层音采障碍炕よるものと考光られる。故に低音域の聴 力損失が 30db 以上である場合は 40phone の騽音下に おいても骨導の閵值移動はないと考学てよい。

4) 騒音下で求められた骨導閾值の検定について 以上の如き測定結果より騒音下で求められた骨導間犆 の検討は次の如く定められる。

先ず第 1 亿 $1000 \mathrm{cps}$ 以下の低音域に 気導㯖力損失の ある場合，元の損失が 3odb 以下であるならば骨導間鹪 の損失む $30 \mathrm{db}$ 以内と考之られるがこの場合，层音系難 聴と見做して骨導閶檤の上杽なしと見做してもよい。

低音域気導聴力損失が 30db 以上であれ机騒音レベル

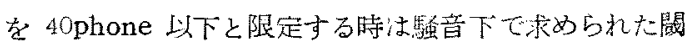

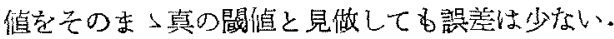

低音淢の気導聴力が正常で高音域気気等聴力損失の古

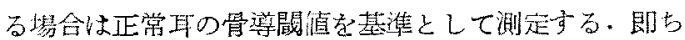

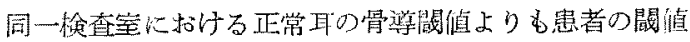

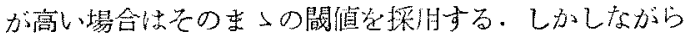

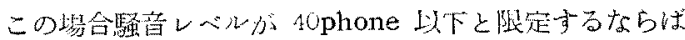
$15 \mathrm{db}$ 以下の誤差が洘光られ 30phone 以下と限定する ならば 5db 以下の愦差が考点られる。

全音域以 気等聴力損失のある場合は低音域の損失が 30db以下である時は先に述べた高音域に気導損失のあ る埸合に準じて同様の検定を行えぱよい．又低音域の気

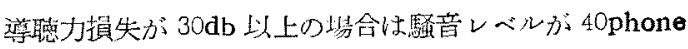

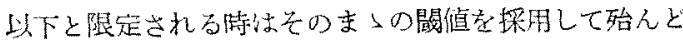
愦美はみとるられない。

\section{第5熘 小括}

一般騷音のレベルを 10phone 以下と限定し，乞の楼 音下で骨導聴力测定が可能であるか否かについて检部し た。

低音域に気導㯖力損失のある場合は平均レベル40 phone 以下の氢音下では誤差の少ない測定值を求める 事ができる。

低音域の気導聴力が正常で高音域のみ損失のある埸 
合，同检查空に和ける正常耳の骨導閾值を基準として測 定すれば，騒音レベルを 40phone 以下と限定すれば $15 \mathrm{db}$ 以内の愦差が考克られ，30phone 以下と限定すれ ば $5 \mathrm{db}$ 以内の捠差が考えられる。

\section{第4章 総括並びに結論}

騒音下に和いてて聴刀検查を施行しなければならない場

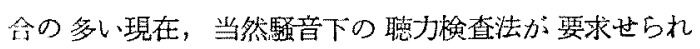

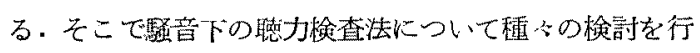
い次の如き結諭を得た。

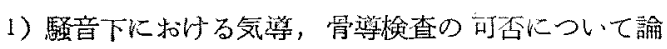
じ踽音許容值を湃定しだ。

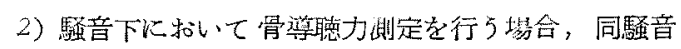
下に和ける聴力正常耳の閔值を基準としてこれを行う事 ができる.この法で测定を行う場合；騷望許容值は約 40phone であり，その際に 5〜10db の愦望を生ずると 考古られる。

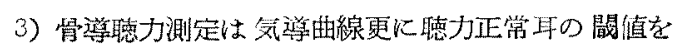
基準としてこれを行う事ができる。この场合騒音許容值

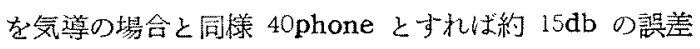
を生ずる可能性がすり 30phone とすれば誤差は $5 \mathrm{db}$ と考它的。

4) 騒音下に执ても騷音レベルに一定の限度を定む れば以上の如く気頱骨導ともにその测定は可能である.

しかしながら上连の鳋音下聴力検查法はあくまで便宜 的なるのであり絶対的なものでない事は䑁り返し述べた 通りである。や学得ない場合，又臨床的に大体の聴力 曲綄を得れば事足りる堎合にこの梌楚法を行らべきであ

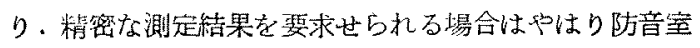
刚で行うべきであるのは云5迄むない事である。

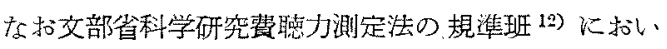

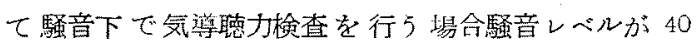

phone では最小可聴值の测定に対する影響が比輘的 少ないので 40phone までは測定に耐え得る。しかしこ

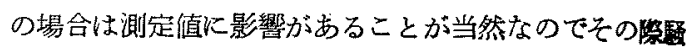
音下に扣ける正常者の最小可聴值 10 耳の平均值を記载 して参考資料とする. 骨導測定る気導測定に準ずると決 定した。

\section{文献}

1) Langenbeck: Arch. Ohr-Nas-Keblk. Heilk. 30, 1932. 2) Weersma: Zeit. Hals-Nas-Ohrenheilk. 47, 1941. 3) Hüizing: Acta. Oto-laryng. Stockholm. 30, 1942. 4) Palva et al: Laryngoscope. 1953, 13. 5) Langenbeck: Zeit. Laryngol. Rhinol. Otolog. 1950, $29 . \quad$ 6) Kietz: Arch. Ohr Nase Kehl, heilk. 1950, 159. 7) Hüizing: Acta. Otolary. 40, 1951. 8) Zangemeister: Arch. Ohr-Nas-

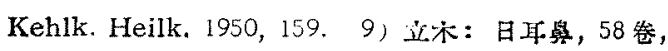
11 북. 10) Langenbeck: Zeit. Laryng. Rhinol. Otol. 1951, 30. 11) Langenbeck: Arch. Ohl-NasKehl. 1950，158. 12）交部省科学研究转聴力測定法

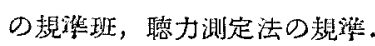

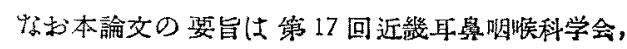
第4回難聴研梦会において発琹したるのである。

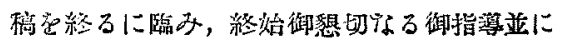

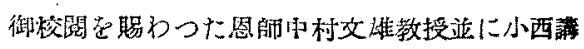
諵に心からなる感謝の意さ裴する。

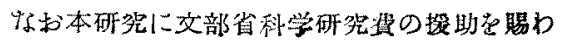

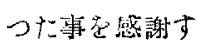

（填稿到着=昭和 31.12.6日） 
THE STANDARD OF HEARING TEST ROOM THE VIEW POINT OF PERMISSIBILITY OF NOISE

Part 2. Hearing test in the noisy room

$$
\text { By }
$$

J. TAKAGI, M.D.

From the Department of Ololaryngology, Kyoto Prefctural Medical College.

(Director: Prof. F. Nakamura)

The auther investigated the method of hearing test under a noisy condition and obtained the following results.

When the noise level in a hearing test room is less than 40 phone, either in the hearing test of air conduction or of bone conduction, the results of the measurement which have few errors are obtained if it is based on the threshold of normal hearing in the hearing test room. 